\title{
Napier Grass Harvest Readiness ${ }^{1}$
}

\author{
Gene L. Spain and Jaime Vélez Santiago ${ }^{2}$
}

\section{INTRODUCTION}

Napier grass (Pennisetum purpureum Schum), a vigorous and highly productive tropical forage, is grown in Puerto Rico for soilage, silage, and pasture (11). Its strong response to heavy applications of fertilizers in humid areas, or with irrigation in dry areas (6), coupled with exceptional tolerance to repeated close cutting, make this grass species especially suitable for intensive management in tropical regions. It is notable also that Napier grass exhibits a tolerance to moisture stress, a factor unusual in a grass of this type requiring relatively large amounts of water for optimum growth $(1,7,14)$.

Although considerable information has been documented concerning Napier grass response to fertilizers $(2,4,6,8,11,12)$, height of cutting $(3,5,11,-$ 13) and intensity of use $(4,8,9,11,12,15)$, little information has accumulated pertaining to harvest readiness of the grass $(S)$. Harvest readiness is considered to be a stage of plant development during which the maximum yield of quality forage can be harvested repeatedly over a period of time suitable to the desired system of management. It is determined by forage yield, its quality, and the morphological and physiological status of the plants; the essential compromises being dependent upon purpose of the planting-whether it is for grazing, for harvesting mechanically, or for short or long duration. The following field experiment with Napier grass was designed to provide practical guidelines for use by both farmers and researchers in determining the harvest readiness of Napier grass.

This paper reports only on the data obtained from tiller measurements, as related to certain selected characteristics.

\section{EXPERIMENTAL PROCEDURE}

An experimental site on San Antón silty clay with a uniform stand of Napier grass of the Merker variety was selected at the Lajas Substation. The area was harvested once uniformly and prepared for flood irrigation. Three harvest regimes were established; at early, intermediate and late harvest stages. These harvests initially were at approximately 40-, 75- and 100-day intervals beginning November 18, 1965. After the first few harvests, however, clipping treatments were adjusted to morphological de-

1 Manuscript submitted to Editorial Board January 10, 1973.

2 Associate Agronomist and Assistant Agronomist, Agricultural Experiment Station, Mayagüez Campus, University of Puerto Rico, Río Piedras, P.R. 
velopment of the plants with the early, intermediate and late harvests occurring when $4-\overline{5}, 7-8$ and 10-12 internodes had elongated to $2.5 \mathrm{~cm}$. or more. These regimes, while not always adhered to strictly, were continued approximately as indicated until the experiment was terminated on February 7,1968 .

At 1- to 2-week intervals after suitable regrowth, 12 tillers were taken randomly from each of the harvest regime plots receiving annual applications of 455,285 and $545 \mathrm{~kg}$. of $\mathrm{N}, \mathrm{P}_{2} \mathrm{O}_{5}$ and $\mathrm{K}_{2} \mathrm{O}$, respectively per hectare. A total of 158 12-tiller samples were examined during the course of the experiment. Fresh and dry weights were determined separately for live leaves, dead leaves and culms; live leaves, dead leaves and internodes

TABLE: 1.-Correlation coefficients calculaled for selecled characleristics of Napier grass wilh various yield componenis

\begin{tabular}{|c|c|c|c|c|c|c|}
\hline \multirow{3}{*}{ Independent variables } & \multicolumn{6}{|c|}{ Dependent variables } \\
\hline & \multicolumn{3}{|c|}{ Total above ground portion } & \multicolumn{3}{|c|}{ Live leaf portion } \\
\hline & $\underset{\text { Fresh }}{\text { weight }}$ & $\underset{\text { weight }}{\text { Dry }}$ & $\begin{array}{c}\text { Crude } \\
\text { protein }\end{array}$ & $\underset{\text { weight }}{\text { Dry }}$ & $\begin{array}{c}\text { Crude protein } \\
\text { (weight) }\end{array}$ & $\begin{array}{c}\text { Crude } \\
\text { protein } \\
\text { (percent) }\end{array}$ \\
\hline Dead leaves (No.) & 0.77 & 0.87 & 0.64 & 0.73 & 0.49 & -0.47 \\
\hline Live leaves (No.) & .83 & .76 & .74 & .80 & .72 & $-.4 \overline{7}$ \\
\hline Internodes (No.) & .91 & .92 & .80 & .91 & .71 & -.68 \\
\hline Culm length $(\%)$ & .89 & .89 & .77 & .86 & .68 & -.63 \\
\hline Dry matter $(\%)$ & .47 & .64 & .44 & .57 & .34 & -.54 \\
\hline Live leaves $(\% / c)$ & -.78 & -.77 & -.68 & -.77 & -.62 & .67 \\
\hline
\end{tabular}

1 All correlations were significant at the 99-percent level of probability. Analyzed values were obtained from 158 12-tiller samples.

longer than $2.5 \mathrm{~cm}$. were counted separately; total culm length was measured; and each component was analyzed for nitrogen by the Kjeldahl method. Total fresh weight, dry weight, percent dry matter and crude protein content were calculated. Harvest treatments were made by clipping entire plots to approximately 5 to $10 \mathrm{~cm}$. above the soil with a Gravely sickle-bar mower. Irrigation was applied when needed to maintain soil moisture adequate though not necessarily optimum for plant growth.

\section{RESULTS AND DISCUSSION}

Several of the plant characters considered appear useful as guides for determining desirable harvest stages of Napier grass. All correlations calculated and shown in table 1, were significant at the 99-percent level of probability. Internode counts were most closely correlated with total fresh weight, dry weight, crude protein, live-leaf dry weight and percent protein, showing correlation coefficients of $0.91,0.92,0.80,0.91$ and -0.68 , respectively. 
This count provides a convenient index to harvest readiness, as the number of elongated internodes is a measure casily determined in the field without instruments. Total culm length gave similar correlations with the same dependent variables and should be considered a satisfactory parameter for determining harvest readiness. Leaf counts might have given equally close correlations if live and dead leaves had been lumped together. However, losses of some lower dead leaves inevitably occur. Live-leaf counts correlated well with total live-leaf dry weight and with live-leaf crude protein, showing coefficients of 0.80 and 0.72 , respectively. Percent of leaves has

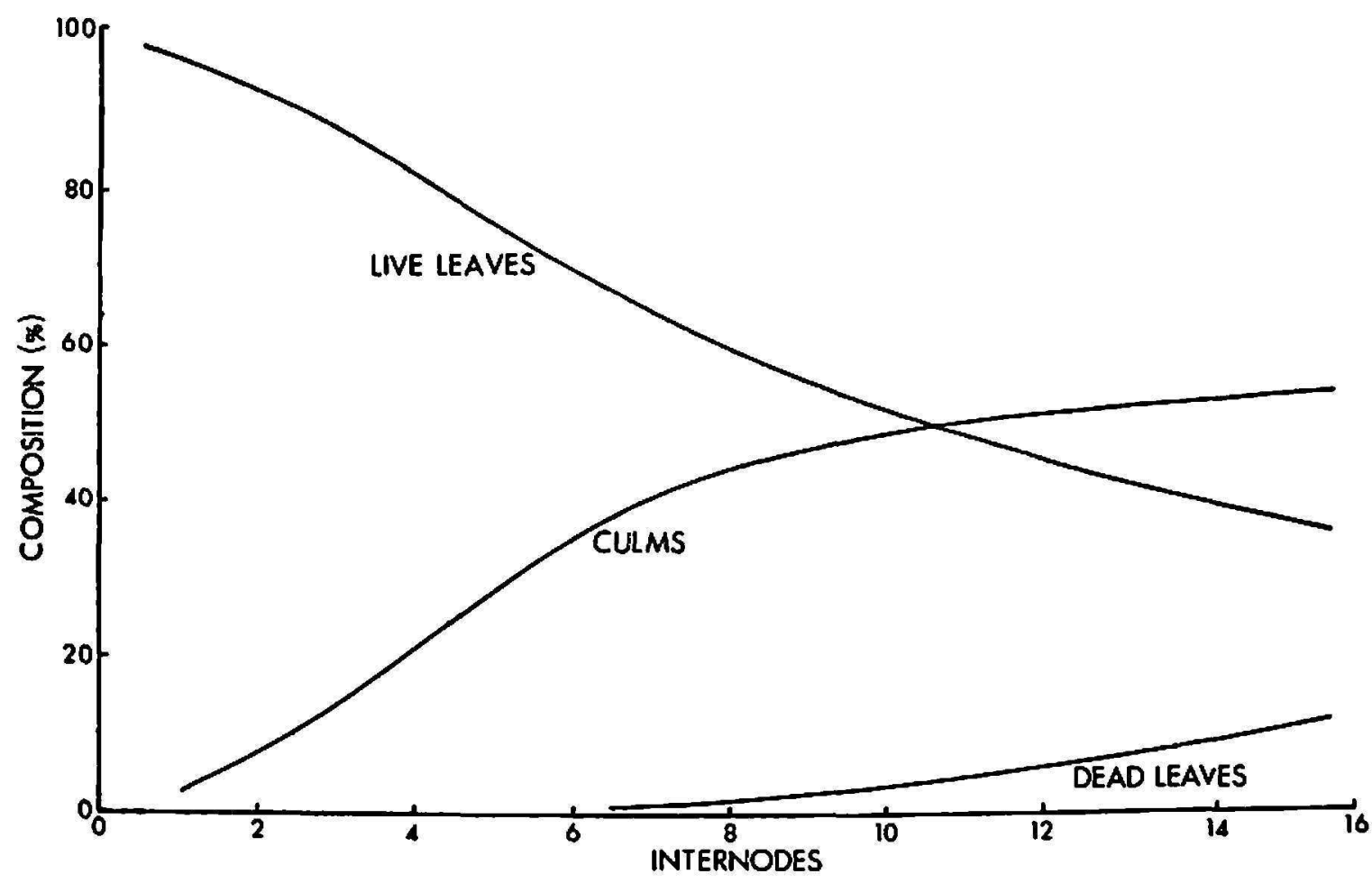

FIG. 1.-Percent composition by live-leaf, culm and dead-leaf components of Napier grass tillers sampled at various stages of culm elongation. Internode counts indicate the number of internodes elongated to $2.5 \mathrm{~cm}$. or more per tiller.

been suggested as a possible guide to harvest readiness (11) and this guide appears suitable according to data obtained in this study. Percent live leaves gave highly significant negative correlation values with all dependent variables except for percent crude protein. Percent crude protein correlated negatively with all other independent variables.

The number of elongated internodes per tiller was the most consistent morphological character considered useful as a guide for harvest readiness of Napier grass. Figures 1, 2 and 3 illustrate relationships between internode counts per tiller and some selected yield components. These illustrations are essentially growth rate curves plotted against a measure of growth other than time. 


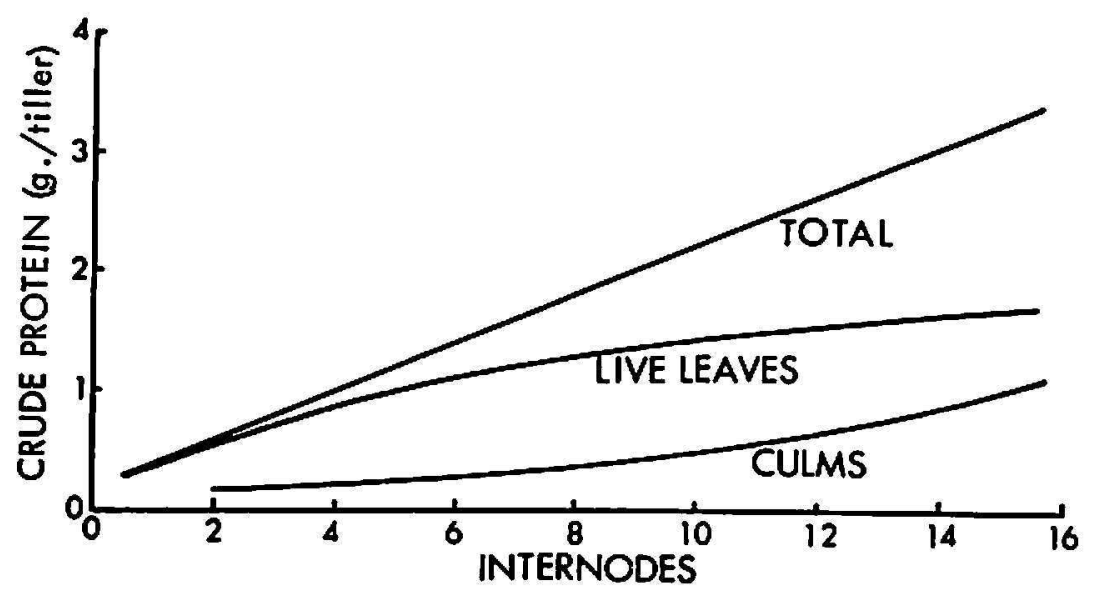

FIG. 2.-Crude protein of total above ground portion, live leaves and culms of Napier grass tillers sampled at various stages of culm elongation. Internode counts indicate the number of internodes elongated to $2.5 \mathrm{~cm}$. or more per tiller.

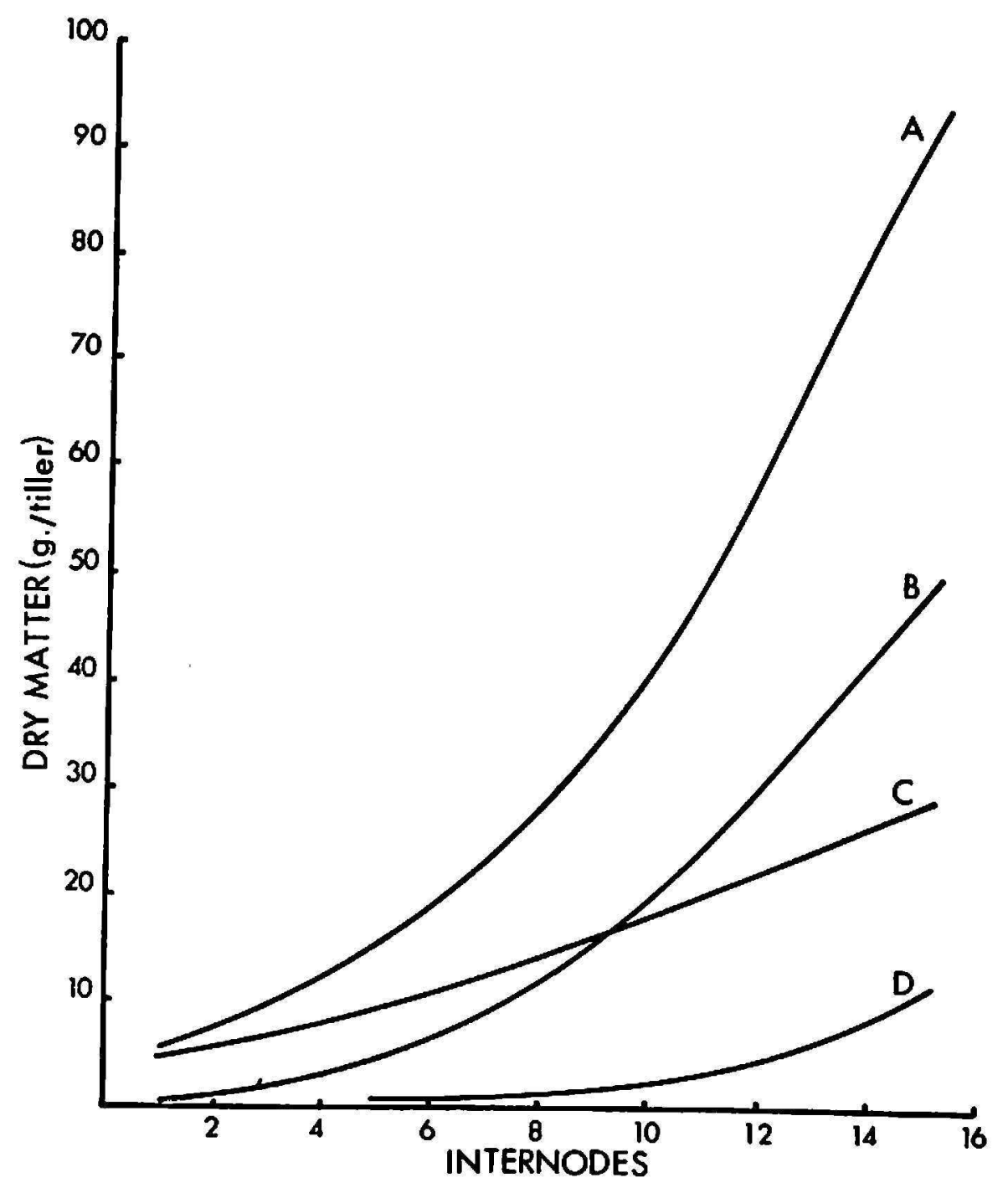

FIG. 3.-Dry matter content of total above ground portion (A), culm (B), live leaves (C) and dead leaves (D) of Napier grass tillers sampled at various stages of culm elongation. Internode counts represent the number of internodes elongated to $2.5 \mathrm{~cm}$. or more per tiller. 
By the time approximately 10 internodes were elongated, the forage composition was about 50 percent leaves and 50 pereent culms (fig. 1). Dead leaves accounted for only a minor portion of the above ground tissue at this growth stage. Beyond the 10-internode stage, curves for live leaves and culms were almost levelling off; this tendency began soon after the 6internode stage of development.

Crude protein production per tiller (fig. 2) reflects the percent composition trends shown in figure 1 , except for the apparent stcepening of the curve for crude protein in the culms during the late growth stages. Protein of the two components shown, live leaves and culms, combined to form a linear relationship $(Y=4.71+0.16 X)$ between total crude protein content $(Y)$ in g. per tiller and internode counts $(X)$.

The rate of increase in total dry matter per tiller (fig. 3) steepened with increasing internode counts through most of the range of these data. This was accounted for by increasing leaf area while sustaining a high efficiency of photosynthesis. It is likely that these curves would have flattened if the data were extended to include tillers with greater numbers of elongated internodes. Although flowering has often occurred by the 14- to 16-internode stage, internodes have been observed to continue development until 20 or more have grown to lengths greater than $2.5 \mathrm{~cm}$., a minimum measure arbitrarily selected for the purpose of this (xperiment.

If total yield were the only consideration, harvests apparently should be delayed until the 12- to 14-internode stage or longer to keep the plant operating in the steepest growth phase. Total crude protein showed a straight-line increase to the 14-internode stage or later; however, live-leaf protein showed a levelling-off trend beginning at a much carlier stage of tiller development. These observations indicate that under intensive management systems of cutting and iereding Napier grass as silage or soilage late harvesting may be desirable, if the animals accept all portions of the harvested material. On the other hand, data from the harvest stage experiment conducted in conjunction with this work showed that harvesting after 7-S internodes had begun elongation resulted in total dry matter yields equal to and crude protein yields greater than later harvesting (8).

Pasturing Napier grass, no doubt, presents a totally different situation. Whether a regrowth response occurs similar to that following mechanical harvesting is not known. If the above data are applicable, they suggest that frequent carly grazing of regrowth would be desired. With grazing, the live-leaf portion is presumably the principal product consumed and the main interest would be in the growth rate and protein content of this component of the plant.

Regardless of the system of management or use to be made of this crop, occasional measurements of one of the considered morphological charac- 
ters of the plant should serve as a useful guide to harvest readiness of Napier grass. Such a guide would be particularly valuable in a research program in which a unit of measure more consistent with the physiological development of the plant could be used as a substitute for the more conventional use of units of time for scheduling harvest treatments.

\section{SUMMARY}

A Napier grass harvest-readiness research project was conducted over a period of $\$ 11$ days at the Lajas Substation, on San Antón silty clay with supplemental irrigation. Harvest frequencies were applied according to internode development of randomly sampled tillers throughout the duration of the experiment.

Number of internodes longer than $2.5 \mathrm{~cm}$. correlated most closely with total fresh weight, total dry weight, total crude protein, live-leaf dry weight and live-leaf percent crude protein, showing correlation coefficients of 0.91 , $0.92,0.80,0.91$, and -0.68 , respectively. Culm length data correlated similarly well. All correlations calculated were significant.

Crude protein and dry matter production per tiller were plotted against number of elongated internodes for each above ground plant component. Also, percent of each plant component of sampled tillers was plotted against internode counts. These curves are useful in estimating desired harvest readiness stages for this species.

The number of elongated internodes or total culm length are suggested as useful practical guides to determine harvest readiness of Napier grass. Harvesting at an intermediate stage when 8 to 10 internodes have begun elongation appears most satisfactory for obtaining high yields of good quality forage.

\section{RESUMEN}

Este estudio se llevó a cabo por un periodo de 811 días en la Subestación de Lajas en un suelo San Antón limo-arcilloso con riego suplementario. El propósito fue establecer normas que pudiesen servir de guia para cosechar la yerba Napier. La frecuencia de las cosechas (cortes) se reguló de acuerdo al desarrollo de los entrenudos de vástagos cogidos al azar y sirvió para establecer las normas respecto a dicha frecuencia.

Los datos indican que hubo una correlación más estrecha entre el número de entrenudos de más de $2.5 \mathrm{~cm}$. y el peso fresco, peso seco, proteína bruta total, y peso seco y porcentaje de proteína bruta de las hojas verdes. Estos arrojaron coeficientes de correlación de $0.91,0.92,0.80,0.91$ y -0.68 , respectivamente. Con respecto al largo de las cañas, la correlación fue similar. Todas las correlaciones fueron significativas.

Se trazó una curva para la producción de proteína bruta y forraje seco por caña en contraste con el número de entrenudos alargados para cada uno de los componentes de la planta sobre el nivel del suelo (cañas, hojas verdes $y$ hojas secas). También, el porcent aje de cada uno de estos componentes se contrastó con el número de entrenu- 
dos contados. Estas curvas son útiles para estimar con facilidad el momento propicio para cosechar esta especie.

El número de entrenudos alargados o Ia longitud total de la caña también se sugieren como guías útiles para determinar dicho momento en el caso de la yerba Napier. El cosechar en una etapa intermedia, cuando de 8 a 10 entrenudos han comenzado a alargarse, parece ser lo más satisfactorio para obtener altos rendimientos de forraje de buena calidad.

\section{LITERATURE CITED}

1. Alexander, A. G., and Spain, G. L., Isolation and properties of Napier grass B-amylase, J. Agr. Univ. P. R. 54 (4): 640-56, 1970.

2. Blaser, R. E., Ritchey, G. E., Kirk, W. G., and Dix Arnold, P. T., Experiments with Napier grass, Univ. Fla. Agr. Exp. Sta. Bull. 568, 32 pp. 1955.

3. Caro Costas, R., and Vicente-Chandler, J., Effects of two cutting heights on yields of five tropical grasses, J. Agr. Univ. P. R. 45 (1): 46-9, 1961.

4. - - - and Figarella, J., The yields and composition of five grasses growing in the humid mountains of Puerto Rico as affected by nitrogen fertilizers, season and harvest procedures, J. Agr. Univ. P. R. 44 (3): 107-20, 1960.

5. Herrera, G. P., Bernal, J. E., Lotero, J. C., Altura de corte en pasto elefante, Agr. Trop. 23 (8): 521-7, 1967.

6. Little, S. N., Vicente-Chandler, J., and Figarella, J., The productivity of irrigated Napier, Guinea, and Pangola grasses as affected by nitrogen fertilization, Agron. J. 51 (2): 111-3, 1959.

7. Pereira, R., Mauro, A., Sykes, D. J., Gomide, J. A., and Vidigal, G. T., Competicao de 10 gramineas para capineiras no cerrado, E.M. 1965. Rev. Ceres 13 (74): 141-53, 1966.

8. Spain, G. L., and Vélez Santiago, J., Yield and quality of Napier grass, Penniselum purpureum Schum., at three harvest stages and three nitrogen levels in Puerto Rico, Agron. Abstr. 840, 1967.

9. Surinam Department of Agriculture, Animal Husbandry and Fisheries Report for 1954, 124 pp., Herbage Abstr. 28: 404, 1958.

10. Takahashi, M., Moomaw, J. C., and lRiperton, J. C., Studies of Napier grass, III, Grazing management, Univ. Hawa i Bull. 128, 47 pp., 1966.

11. Vicente-Chandler, J., Caro Costas, R., Pearson, R. W., Abruña, F., Figarella, J., and Silva, S., The intensive management of tropical forages in Puerto Rico, Agr. Exp. Sta., Univ. P.R. Bull. 187, 152 pp., 1964.

12. - Silva, S., and Figarella, J., Effects of nitrogen fertilization and frequency of cutting on the yield and composition of Napier grass in Puerto Rico, J. Agr. Univ. P.R., 43 (4): 215-27, 1959.

13. Werner, J. C., Pereira, L. F., Martinelli, J), and Cintra, B., Study of 3 cutting heights with Napier grass, Bol. Ind. Anim. 23: 161-8, 1965-66, Herbage Abstr. 38: 68, 1968.

14. Whyte, R. O., Moir, T. R. G., and Cooper, J. P., Las gramineas en la agricultura, FAO, Estudios Agropecuarios No. 42, Rome, Italy, 464 pp. 1959.

15. Wilsie, C. P., Akamine, E. K., and Takahashi, M., Effect of frequency of cutting on the growth, yield, and composition of Napier grass, J. Amer. Soc. Agron., $32: 266-73,1940$. 